\title{
Hambatan E-learning Terhadap Pembelajaran Matematika di Sekolah Menengah Pertama
}

\author{
Faza Syamila $^{1}$, Fitri Alyani ${ }^{2}$ \\ ${ }^{1,2}$ Pendidikan Matematika, Fakultas Keguruan dan Ilmu Pendidikan, Universitas Muhammadiyah Prof. Dr. HAMKA, \\ Jl. Tanah Merdeka No 20, Jakarta Timur, Indonesia \\ fitrialyani@uhamka.ac.id
}

\begin{abstract}
Currently, Indonesia is spreading the spread of COVID-19, one of which is in education. Learning currently uses online-based learning or called e-learning. E-learning is a learning activity that is carried out through electronic media and is accessed by the internet network. With e-learning-based mathematics learning, students use learning media. This learning media can be accessed through the internet network, so that students experience problems in e-learning-based mathematics learning. This study aims to find facts related to e-learning barriers to learning mathematics. This study uses a quantitative approach and a qualitative approach. The quantitative approach uses the Rasch model with data collection techniques using questionnaires, a qualitative approach using interview techniques. In a study conducted in junior high schools in the Jakarta and Tangerang areas. The sample of this study was 143 respondents in class VII, VIII and IX. The results of this study that students experience unstable internet network barriers, limited internet quota and students do not have electronic media devices to support the learning process.
\end{abstract}

Keywords: Mathematical Problem-Solving Ability, Mathematical Disposition, Comparison

\begin{abstract}
Abstrak
Saat ini indonesia terdampak penyebaran covid-19 salah satu nya dalam lembaga pendidikan. Pembelajaran saat ini menggunakan pembelajaran berbasis online atau disebut dengan e-learning. E-learning merupakan kegiatan pembelajaran yang dilakukan melalui elektronik media serta terakses dengan jaringan internet. Dengan pembelajaran matematika berbasis e-learning siswa menggunakan media pembelajaran. Media pembelajaran ini diakses melalui jaringan internet, sehingga siswa mengalami kendala dalam pembelajaran matematika berbasis $e$ learning. Penelitian ini bertujuan untuk menemukan fakta yang berkaitan dengan hambatan e-learning terhadap pembelajaran matematika. Penelitian ini menggunakan pendeketan kuantitatif dan pendekatan kualitatif. Pendekatan kuantitatif menggunakan rasch model dengan teknik pengumpulan data menggunakan menyebar kuesioner sedangkan pendekatan kualitatif menggunakan teknik wawancara. Dalam penelitian dilakukan di sekolah menengah pertama di daerah Jakarta dan Tanggerang. Sampel penelitian ini sebanyak 143 responden kelas VII, VIII dan IX. Hasil dari penelitian ini bahwa siswa mengalami hambatan jaringan internet tidak stabil, terbatasnya kouta internet dan siswa tidak memiliki perangkat elektronik media untuk menunjang proses pembelajaran.
\end{abstract}

Kata kunci: E-learning, Pembelajaran Matematika, Rasch Model

Copyright (c) 2021 Faza Syamila, Fitri Alyani

$\square$ Corresponding author: Fitri Alyani

Email Address: fitrialyani@uhamka.ac.id (Jl. Tanah Merdeka No. 20, Jakarta Timur, Indonesia)

Received 15 June 2021, Accepted 01 July 2021, Published 03 July 2021

\section{PENDAHULUAN}

Dalam proses pembelajaran matematika terdapat interaksi guru dan siswa. Interaksi tersebut memudahkan siswa untuk mengetahui materi yang disampaikan oleh guru, Namun proses pembelajaran matematika terdapat hambatan belajar sehingga siswa berdampak terhadap hasil belajar yang kurang maksimal. Hambatan belajar (learning obtacles) adalah kesulitan dalam proses pembelajaran sehingga siswa tersebut menyebabkan hasil belajar yang tidak optimal (Balkist, 2020). Sejalan dengan (Suyedi \& Idrus, 2019) menyatakan bahwa dalam lingkungan belajar, guru tentunya mengharapkan siswa untuk mencapai hasil belajar yang maksimal, namun banyak yang mengalami hambatan belajar ketika dihadapi oleh siswa saat mereka menerima materi untuk mencapai hasil belajar yang memuaskan. Ada beberapa 
faktor-faktor yang menjadi hambatan belajar yang dialami oleh siswa menurut Brousseau adalah: 1) Hambatan Ontogeni (ketidaksesuain antara pembelajaran dengan tingkat berfikir siswa), 2) Hambatan Didaktis (kesulitan dalam proses pembelajaran akibat pengajaran guru), 3) Hambatan Epistimologis (kesulitan dalam proses pembelajaran yang terdapat pada pengetahuan siswa yang memiliki konteks aplikasi yang terbatas) (Wahyuni, 2017).

Pembelajaran matematika merupakan pembelajaran yang diajarkan mulai dari Sekolah Dasar hingga sampai Perguruan Tinggi (Siswa et al., 2017). Matematika tidak dapat terlepas dari kegunaan pada setiap aspek kehidupan manusia dikarenakan dapat digunakan di berbagai bidang seperti kesehatan dan bidang lainnya (Aditya, 2018). Maka dari itu matematika sangat berperan penting dalam aspek kehidupan manusia termasuk dalam bidang pendidikan. Pembelajaran matematika berfungsi untuk mengembangkan kemampuan secara berpikir kritis, logis, kreatif serta mampu membantu siswa dalam kehidupan modern (Hal et al., 2017).

Saat ini Indonesia terdampak penyebaran Coronavirus Disease (Covid-19) salah satu nya dalam lembaga pendidikan. Pendidikan diindonesia dengan melalui Menteri Pendidikan dan Kebudayaan Republik Indonesia mengeluarkan Surat Edaran Nomor 4 Tahun 2020 Tentang Pelaksanaan Kebijakan Pendidikan Masa Darurat Penyebaran Covid-19 poin ke 2 yaitu proses pembelajaran dari rumah dilaksanakan dengan berbagai ketentuan sebagai berikut : a. Belajar dari rumah melalui pembelajaran daring/jarak jauh dilaksanakan untuk memberikan pengalaman belajar yang bermakna bagi sisa tanpa terbebani tuntutan menuntaskan seluruh capaian kurikulum untuk kenaikan kelas maupun kelulusan, b. Belajar dari rumah dapat difokuskan pada pendidikan kecakapan hidup antara lain mengenai pandemi covid-19, c. Aktivitas dan tugas pembelajaran belajar dari rumah dapat bervariasi antarsiswa, sesuai dengan minat dan kondisi masing-masing termasuk mempertimbangkan kesenjangan akses/fasilitas belajar dari rumah, d. Bukti atau produk aktivitas belajar dari rumah diberi umpan balik yang bersifat kualitatif dan berguna dari guru, tanpa harus memberi skor/nilai kuantitatif. Sehingga pendidikan di indonesia dalam proses pembelajarannya menggunakan berbasis online atau disebut dengan e-learning.

E-learning merupakan kegiatan pembelajaran yang dilakukan melalui elektronik media (Agustina, 2013; Alariqi et al., 2019). Menurut Onno W. Purbo, pengertian e-learning adalah sebuah teknologi untuk mendukung pembelajaran yang melalui elektronik yang menggunakan jaringan internet (Arifin \& Herman, 2018). E-learning mampu menjadikan siswa lebih mandiri dalam proses pembelajaran. Sama hal nya dengan ciri-ciri dalam pembelajaran berbasis e-learning adalah siswa mampu belajar secara mandiri dan siswa lebih mampu mengelola proses pembelajarannya secara sendiri termasuk dalam hal mengatur lingkungan, memotivas terhadap diri sendiri, memahami pengetahuan secara mandiri, proaktif serta penuh dengan pertimbangan (Noor et al., 2017). Pembelajaran berbasis e-learning bukan menggantikan model belajar yang konvensional didalam kelas hanya saja memperkuat model belajar dengan melalui pengayaan content serta pengembangan teknologi dalam dunia pendidikan (Sawitri et al., 2019). Pembelajaran $e$ learning ini dapat dilakukan menggunakan aplikasi pembelajaran seperti Google classroom, Zoom, YouTube, Google Meet dan aplikasi lainnya yang diakses menggunakan jaringan internet. 
Dalam pembelajaran berbasis e-learning siswa mengalami hambatan seperti bermasalah dalam jaringan internet, terbatasnya pengetahuan dalam penggunaan e-learning serta siswa tidak memiliki alat elektronik media untuk menunjang proses pembelajaran. Sehingga terdapat sebuah kenyataan yang sudah dilakukan bahwa ada beberapa hambatan dalam pembelajaran matematika berbasis e-learning yaitu keterbatasan pemahaman siswa dalam penggunaan pembelajaran matematika berbasis e-learning (Johar \& Subianto, 2019). Maka hal ini masih terdapat kendala dalam proses pembelajaran matematika berbasis $e$ learning.

Menurut (Mailizar et al., 2020) pendidikan saat ini pembelajaran menggunakan pembelajaran berbasis e-learning sehingga penting untuk menyelidiki hambatan e-learning dari sudut pandang guru. Sehingga hambatan e-learning ini dapat dialami oleh guru maupun siswa. Penelitian ini memiliki tujuan yaitu untuk menemukan fakta yang berkaitan dengan hambatan e-learning dalam pembelajaran matematika.

\section{METODE}

Penelitian ini menggunakan pendekatan kuantitatif dan kualitatif. Penelitian tersebut menganalisis tentang hambatan e-learning terhadap pembelajaran matematika di sekolah menengah pertama. Dalam penelitian dilakukan di Sekolah Menengah Pertama (SMP) di daerah Jakarta dan Tanggerang. Sampel penelitian sebanyak 143 siswa kelas VII, VIII, dan IX tahun ajaran 2021/2022.

Pendekatan kuantitatif menggunakan Rasch Model. Dalam Rasch Model tidak menunjukkan nilai yang bergantung pada besarnya skor, tetapi nilai logit yang menunjukkan probabilitas dengan suatu item dalam kelompok responden (Muntazhimah et al., 2020). Menurut (Sumintono \& Widhiarso, 2015) memahami rasch model dibandingkan metode lain, terutama dalam teori tes klasik yaitu untuk prediksi data yang hilang yang didasarkan pada pola respon. Dalam teknik pengumpulan data dan informasinya melalui instrument angket responden siswa dengan menggunakan Google Form. Dalam Google From untuk menyebar kuesioner atau angket dapat diakses melalui link yang dibagikan kepada responden, dan peneliti dapat mencari referensi yang relevan sesuai dengan permasalahan yang telah ditemukan (Utami et al., 2020). Kuesioner tersebut terdapat 25 pernyataan yang berkaitan dengan hambatan e-learning terhadap pembelajaran matematika dan dalam penelitian ini menggunakan skala likert terdiri dari Sangat Tidak Setuju (STS), Tidak Setuju (TS), Setuju (S) dan Sangat Setuju (SS). Dalam pengolahan data menggunakan aplikasi Winstep.

Tabel 1. Demografi dari Responden

\begin{tabular}{|c|c|c|c|}
\hline Demografi & & Huruf & Jumlah \\
\hline \multirow{2}{*}{$\begin{array}{c}\text { Pernyataan } \\
\text { Setiap Item }\end{array}$} & Item & I & 20 Pernyataan \\
\hline \multirow{3}{*}{ Kelas } & 7 & $\mathrm{~A}$ & 38 \\
\cline { 2 - 4 } & 8 & $\mathrm{~B}$ & 73 \\
\cline { 2 - 4 } & 9 & $\mathrm{C}$ & 32 \\
\hline \multirow{2}{*}{ Jenis Kelamin } & Perempuan & $\mathrm{P}$ & 81 \\
\cline { 2 - 4 } & Laki-Laki & $\mathrm{L}$ & 62 \\
\hline
\end{tabular}




\begin{tabular}{|c|c|c|c|}
\hline Status Sekolah & Negeri & N & 24 \\
\cline { 2 - 4 } & Swasta & S & 119 \\
\hline
\end{tabular}

Contoh terdapat respon "019LSC" maka responden tersebut adalah responden urutan ke-19 laki-laki dan sekolah swasta kelas 9 dapat dilihat pada Tabel 2 .

Tabel 2. Informan Dalam Wawancara

\begin{tabular}{|c|c|c|c|}
\hline Kategori & Responden & Jenis Kelamin & Total Score \\
\hline Sangat Tinggi & 057LSB (R1) & Laki-Laki & 100 \\
\hline Sedang & 061PSB (R2) & Perempuan & 75 \\
\hline Sangat Rendah & 019LSC (R3) & Laki-Laki & 50 \\
\hline
\end{tabular}

Pada pendekatan kualitatif menggunakan teknik wawancara. Menurut Esterbeg wawancara merupakan terdapat dua orang yang saling bertukar informasi serta memiliki ide dengan melalui tanya jawab supaya mengacu pada suatu topik (Glinka, 2008). Dalam wawancara yang dilakukan peneliti adalah wawancara yang telah disiapkan sesuai dengan permasalahan yang diajukan dalam bentuk pertanyaan (Rully Amrizal, 2016). Dalam analisis data peneliti menggunakan wawancara terstruktur mengacu pada kuesioner, tetapi wawancara tersebut tidak berupa tulisan melainkan dalam bentuk lisan yang dilakukan oleh pewawancara dan hasil dari wawancara responden tersebut direkam. Wawancara ini mendapatkan informan yaitu berdasarkan yang memiliki hambatan e-learning terhadap pembelajaran matematika yang tergolong sangat tinggi, sedang dan sangat rendah. Kemudian data tersebut dalam bentuk teks naratif tentang hambatan e-learning terhadap pembelajaran matematika. Setelah itu dilakukan penarikan kesimpulan serta terdapat verifikasi yang akan menjadi temuan baru yang berkaitan dengan hambatan e-learning terhadap pembelajaran matematika untuk masing-masing subjek penelitian.

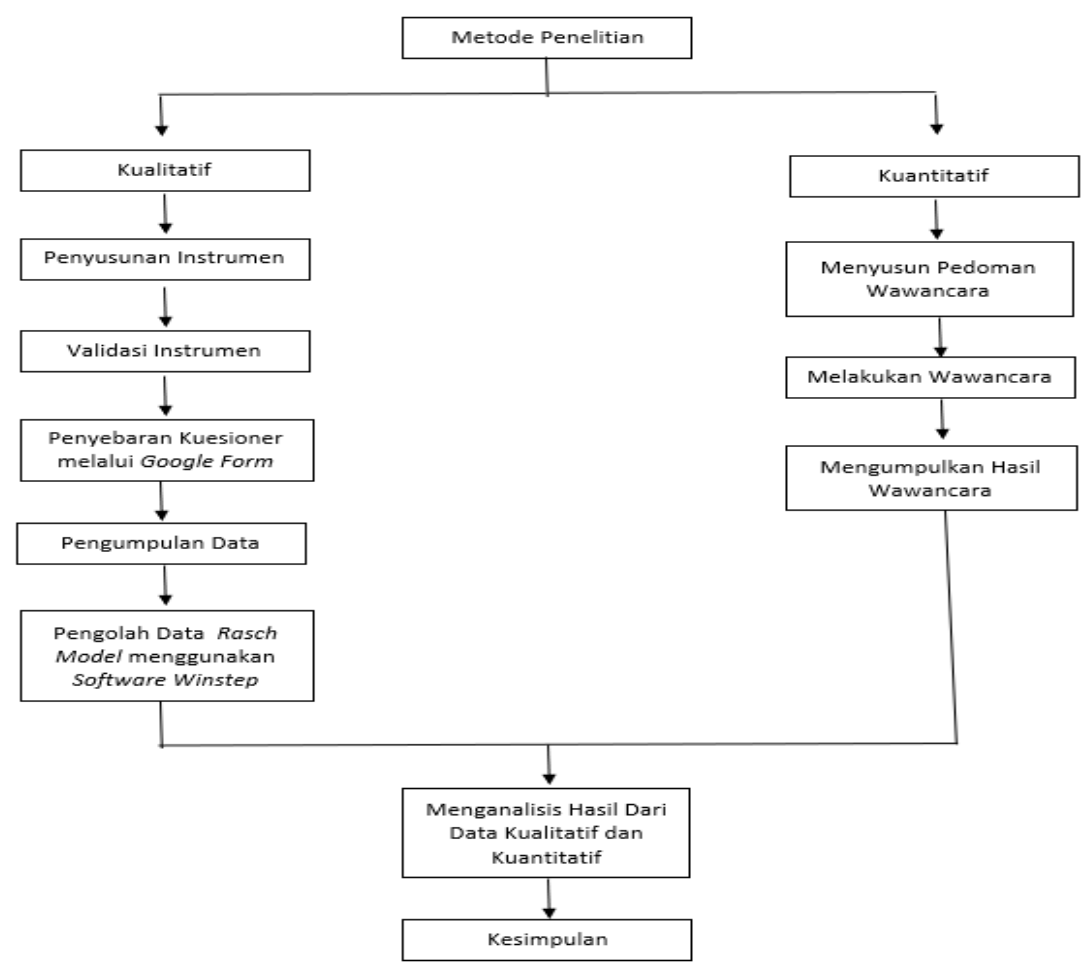

Gambar 1 Road Map Penelitian 


\section{HASIL DAN DISKUSI}

Tabel 3. Summary Statistic of Measured Person and Item

\begin{tabular}{|c|c|c|c|c|c|}
\hline & Mean & SD & Separation & Reliability & Alpha Cronbach \\
\hline Person & 0,53 & 0,61 & 1,80 & 0,76 & 0,79 \\
\hline Item & 0,00 & 0,42 & 3,86 & 0,94 & - \\
\hline
\end{tabular}

Dalam Tabel 1 menunjukkan bahwa nilai rata-rata person adalah 0,53 dan nilai rata-rata item adalah 0,00 maka hal ini menunjukan bahwa siswa cenderung mudah dalam menjawab setiap angket (item). Nilai Reliability Person sebesar 0,76 dan nilai Reliability Item sebesar 0,94 sehingga dapat disimpulkan bahwa siswa memiliki konsistensi jawaban dan kualitas butir-butir soal yang tergolong bagus (Fitri Alyani, 2020).

Nilai Alpha Cronbach untuk mengukur reliabilitas yaitu interaksi person dan butir-butir secara keseluruhan (Sumintono \& Widhiarso, 2015). Sehingga nilai Alpha Cronbach adalah 0,79 sehingga dapat disimpulkan bahwa nilai Alpha Cronbach menyatakan bahwa interaksi antara person dengan butir soal secara keseluruhan sangat bagus (Purba, 2018). Jadi kesimpulannya instrumen telah sesuai untuk hambatan e-learning terhadap pembelajaran matematika dan secara keseluruhan item telah sesuai.

Pengelompokan person dan butir dapat diketahui dari nilai separation (Sumintono \& Widhiarso, 2015). Nilai item separation adalah 3,86. Sehingga hasil perhitungan diperoleh dari item separation sebesar 5,48 dalam hal ini semakin besar nilai separation maka kualitas instrumen dari keseluruhan responden dan butir-butir soal tergolong bagus.

Wright Maps menggambarkan sebaran kemampuan siswa dan mampu mengambarkan tingkatan kesulitan setiap butir-butir soal (Sumintono \& Widhiarso, 2015). Terdapat data Wright Maps Of Person menunjukan bahwa hasil responden dapat dibagi 5 kelompok besar diantaranya yaitu, kelompok sangat tinggi yaitu responden yang memiliki tingkat hambatan e-learning tergolong sangat tinggi terdapat 3 responden, kelompok tinggi yaitu responden yang memiliki tingkat hambatan e-learning tergolong tinggi terdapat 2 responden, kelompok sedang yaitu responden yang memiliki tingkatan hambatan e-learning tergolong sedang terdapat 14 responden, kelompok rendah yaitu responden yang memiliki hambatan $e$ learning yang tergolong rendah terdapat 98 responden dan kelompok sangat rendah yaitu responden yang memiliki hambatan e-learning yang tergolong sangat rendah terdapat 26 responden. Maka untuk pengelompokkan responden dan item dapat diketahui harus dari indeks separation.

Gambar 1 berikut menunjukan bahwa terdapat sejumlah responden yang memilki pola respon dengan unik (Ardiyanti, 2017). Sehingga dalam analisis tersebut diperoleh bahwa untuk responden 057LSB, 091LNB dan 001PNB memiliki tingkatan kesukaran sangat tinggi maka hal ini menyatakan bahwa responden memiliki hambatan e-learning terhadap pembelajaran matematika yang sangat tinggi, sedangkan responden 003PNB, 013LSB, 017LSB, 024PSC, 026PSB, 037PSC, 049LSA, 052LSA, 077LSA, 082LNB, 096LSB, 100LSB, 034PNA, 067PSB, 074PSA, 076LSB, 079LSA, 102LSB, 108LSB, 123PSB, 027PSC, 055LSA, 097LSB, 113PSA, 137PSC dan 019LSC menyatakan bahwa responden memiliki hambatan $e$-learning terhadap pembelajaran matematika yang sangat rendah. 


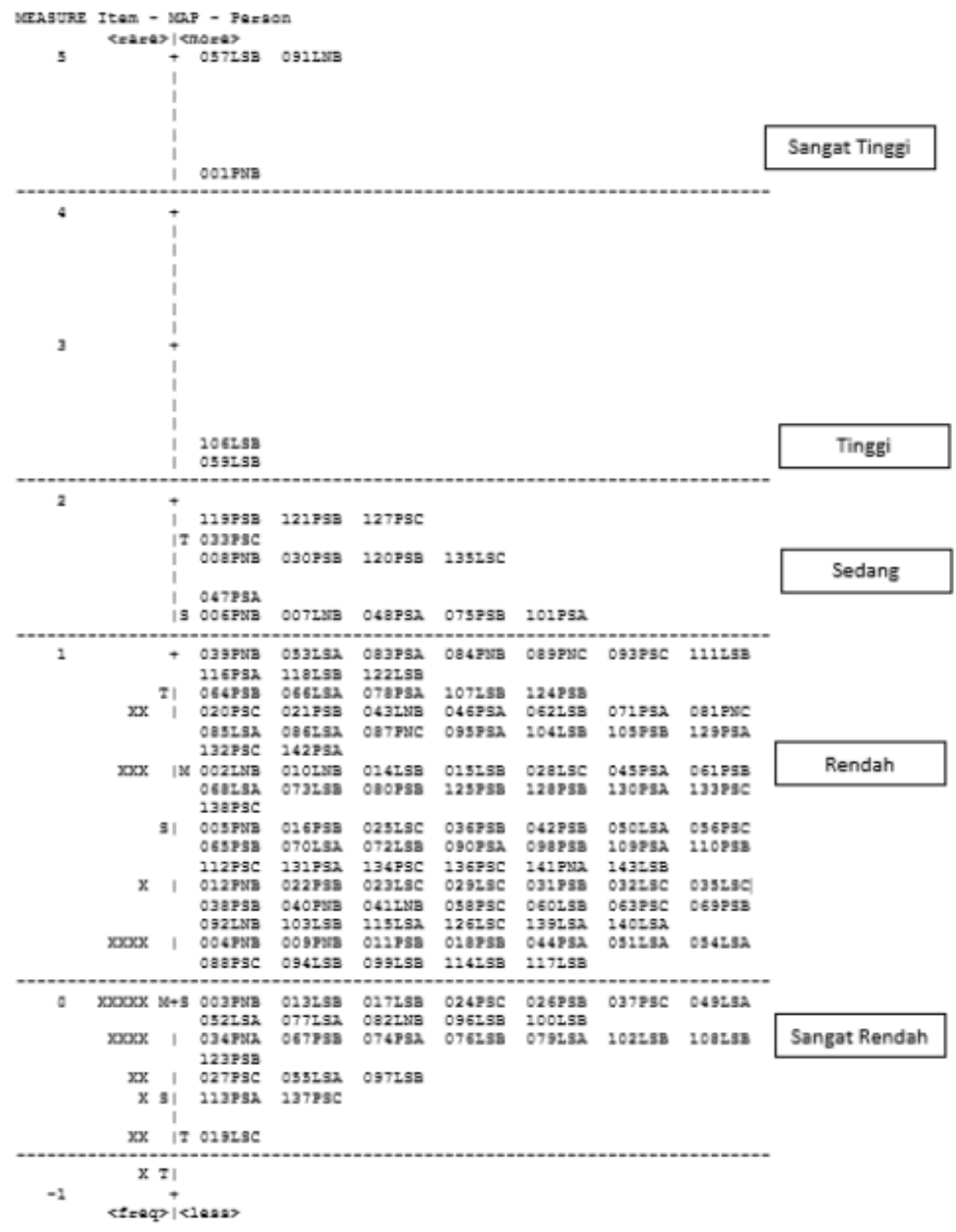

Gambar 1. Wright Maps of Person

Dalam Gambar 2 berikut diperoleh data Wright Maps Of Item bahwa terdapat 25 pernyataan atau item yang telah diuji melalui aplikasi Winstep. Sehingga dalam item tersebut terdapat item dengan tingkat kesulitan tertinggi yaitu angket 12 dan 14. Pada angket 12 menyatakan bahwa "saya tidak memiliki perangkat (misalnya: laptop dan handphone) untuk penggunaan e-learning". Sedangkan pada angket 14 menyatakan bahwa " saya tidak memiliki koneksi internet untuk menunjang proses pembelajaran matematika berbasis e-learning". Pada soal dengan tingkat kesulitan terendah terdapat pada angket 17 yang menyatakan bahwa "saya tidak dapat mengakses materi jika tidak ada internet".

Berdasarkan analisis dari wright map person and item menyatakan bahwa terdapat 37 siswa atau responden yang menyetujui pernyataan 12 dan 14 maka hal ini responden tersebut memiliki hambatan $e$ learning terhadap pembelajaran matematika yang sangat tinggi sedangkan yang memiliki hambatan $e$ learning terhadap pembelajaran matematika yang sangat rendah terdapat 26 responden yang menyetujui pernyataan yang telah menyetujui pernyataan 11, 15, 19, 2, 21, 1, 20, 8, 9, 10, 16, 25, 18, 4 dan 17. 


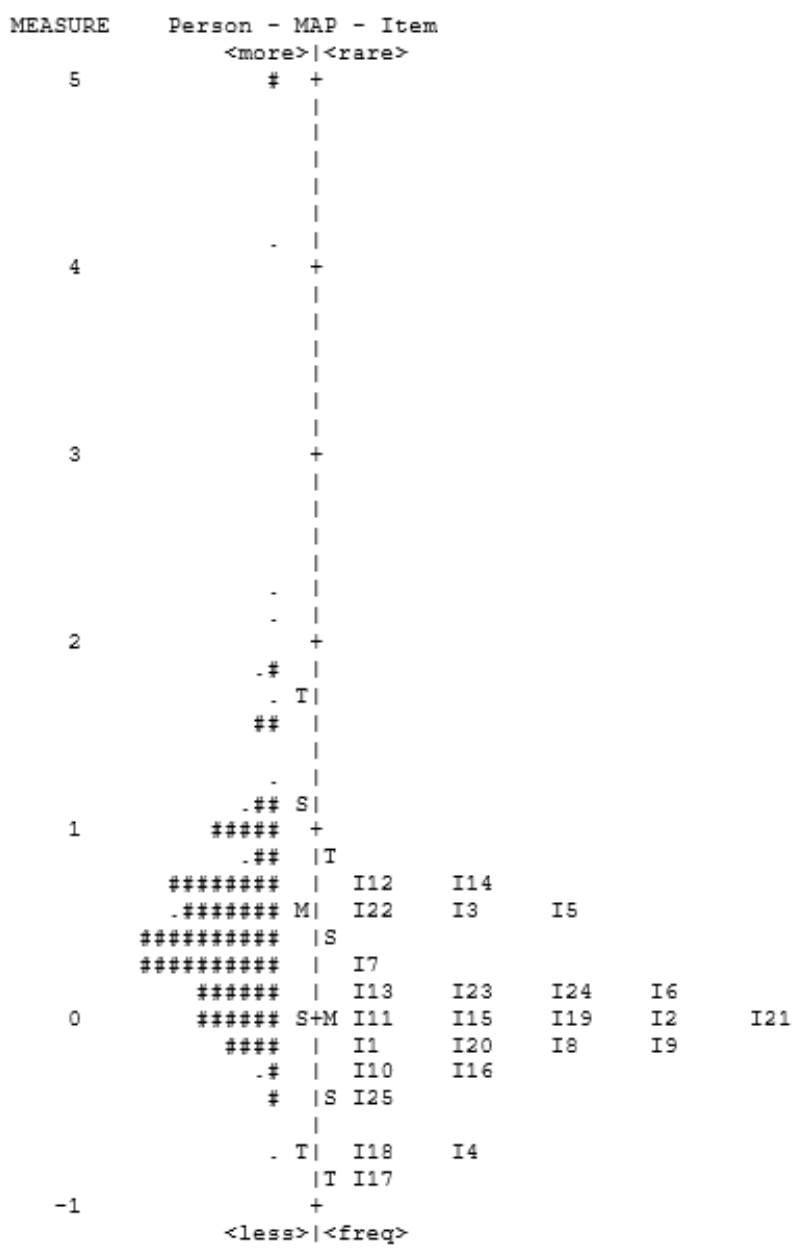

Gambar 2. Wright Maps Of Item

Selanjutnya, dilakukan wawancara terhadap siswa yang memiliki hambatan e-learning terhadap pembelajaran matematika yang tergolong sangat tinggi, sedang dan sangat rendah. berikut hasil wawancara tersebut:

\section{Responden dengan kategori hambatan e-learning tergolong sangat tinggi $(R 1)$}

Saya : Apa yang kamu ketahui tentang pembelajaran matematika berbasis e-learning ?

Responden : Pembelajaran matematika yag dilakukan secara online.

Saya : Apa saja yang menjadi hambatan e-learning dalam proses pembelajaran matematika?

Responden : Saya masih terkendala dengan jaringan internet karena dalam proses pembelajaran matematika menggunakan aplikasi pembelajaran sehingga butuh mengaksesnya dengan koneksi internet.

Saya : Bagaimana kamu mengatasi hambatan e-learning dalam proses pembelajaran matematika?

Responden : Saya sebelum pembelajaran matematika dimulai harus mempersiapkan jaringan internetnya.

Saya : Selama pembelajaran matematika berbasis e-learning ini guru menggunakan model 


\begin{abstract}
pengajaran apa?
Responden : Biasa nya guru saya hanya mengasih materi melalui google classroom sehingga guru tidak menjelaskan materi tersebut dan saya merasa kurang paham apalagi yang berkaitan dengan rumus matematika

Saya : Selama pembelajaran matematika berbasis e-learning ini kamu mengakses materi melalui perangkat apa?

Responden : Saya menggunakan Handphone dan itu milik orang tua saya.

Saya : Bagaimana dengan hasil belajar matematika kamu selama berbasis e-learning?

Responden : Selama pembelajaran matematika berbasis e-learning saya sering remedial karena saya tidak paham dengan beberapa materi yang sudah diajarkan oleh guru.

Saya : menurut kamu, apakah pembelajaran matematika berbasis $e$-learning ini efektif atau tidak ?

Responden : Kalau menurut saya tidak ka karena pembelajaran matematika itu berkaitan dengan rumus dan angka sehingga harus dilakukan pembelajarannya secara langsung dan harus berinteraksi dengan guru.
\end{abstract}

Berdasarkan wawancara yang telah dilakukan terlihat bahwa responden (R1) yang memiliki hambatan e-learning terhadap pembelajaran matematika tergolong sangat tinggi mampu menjawab pertanyaan yang diajukan oleh pewawancara dengan jelas dan sesuai dengan pertanyaan. Responden yang tergolong sangat tinggi menyatakan bahwa responden masih terkendala dengan jaringan internet dan guru tidak menjelaskan materi yang telah diberikan hanya memberikan materi dan tugas melalui google classroom sehingga responden tersebut tidak paham dengan pembelajaran matematika terutama mengenai rumus-rumus atau teori tentang matematika.

2. Responden dengan kategori hambatan e-learning tergolong sedang (R2)

Saya : Apa yang kamu ketahui tentang pembelajaran matematika berbasis e-learning ?

Responden : Pembelajarannya dilakukan secara daring dan terhubung dengan jaringan internet.

Saya : Apa saja yang menjadi hambatan e-learning dalam proses pembelajaran matematika?

Responden : hambatan nya mungkin saya jadi kurang paham dengan materi yang diajarkan karena pembelajaran matematika sekarang melalui aplikasi pembelajaran seperti zoom, dan google classroom.

Saya : Bagaimana kamu mengatasi hambatan e-learning dalam proses pembelajaran matematika?

Responden : jika saya tidak paham dengan suatu materi saya mennayakan langsung ke guru melalui whatsapp

Saya : Selama pembelajaran matematika berbasis e-learning ini guru menggunakan model pengajaran apa?

Responden : guru mengajarkan melalui google classroom dan seminggu sekali melalui zoom karena guru saya jika yang berkenaan dengan rumus atau teori matematika melalui aplikasi zoom 
sedangkan untuk tugas melalui google classroom.

Saya : Selama pembelajaran matematika berbasis e-learning ini kamu mengakses materi melalui perangkat apa?

Responden : Saya menggunakan Handphone untuk megikuti pembelajaran matematika berbasis elearing.

Saya : Bagaimana dengan hasil belajar matematika kamu selama berbasis e-learning?

Responden : Selama pembelajaran matematika berbasis e-learning hasil belajar saya sedikit menurun ka karena ada beberapa materi yang kurang saya paham.

Saya : menurut kamu, apakah pembelajaran matematika berbasis e-learning ini efektif atau tidak ? Responden : kurang efektif ka karena hambatan pembelajaran online ini banyak yang dialami oleh guru maupun siswa sedangkan pembelajaran matematika berhubungan dengan angka dan rumus jadi perlu bertahap belajarnya.

Berdasarkan wawancara yang telah dilakukan terlihat bahwa responden (R2) yang memiliki hambatan e-learning terhadap pembelajaran matematika tergolong sedang mampu menjawab pertanyaan yang diajukan oleh pewawancara dengan jelas dan sesuai dengan pertanyaan. Responden yang tergolong sedang menyatakan bahwa responden masih terkendala dengan pemahaman materi yang diajarkan oleh guru dan responden mengalami sedikit penurunan terhadap hasil belajar matematika. Responden juga mengatakan pembelajaran matematika berbasis online ini kurang efektif karena hambatan ini dapat dialami oleh guru dan siswa sehingga pembelajaran matematika perlu bertahap dalam belajarnya.

3. Responden dengan hambatan e-learning tergolong sangat rendah $(R 3)$

Saya: Apa yang kamu ketahui tentang pembelajaran matematika berbasis e-learning?

Responden: Pembelajaran matematika yang dilakukan secara online.

Saya: Apa saja yang menjadi hambatan e-learning dalam proses pembelajaran matematika?

Responden: Paling hambatan yang saya alami selama pembelajaran matematika berbasis e-learning yaitu penggunaan aplikasi pembelajaran ka karena selama pembelajaran matematika menggunakan aplikasi jadi agak ribet dan pemahaman materi juga sedikit kurang paham jika diajarkan oleh guru. Saya: Bagaimana kamu mengatasi hambatan e-learning dalam proses pembelajaran matematika? Responden: Jika saya mnegalami hambatan dalam aplikasi saya meminta bantua ke kakak.

Saya: Selama pembelajaran matematika berbasis e-learning ini guru menggunakan model pengajaran apa?

Responden: Guru menjelaskan materi hanya melalui google classroom ka dan saya kurang paham dalam penggunaan aplikasi tersebut.

Saya: Selama pembelajaran matematika berbasis e-learning ini kamu mengakses materi melalui perangkat apa?

Responden: Saya menggunakan Handphone untuk megikuti pembelajaran matematika berbasis $e$ learing. 
Saya: Bagaimana dengan hasil belajar matematika kamu selama berbasis e-learning?

Responden: sengan pembelajaran matematika berbasis online hasil belajar saya menurun ka karena saya tidak paham dengan materi yang diajarkan oleh guru dan pembelajaran matematika merupakan pembelajaran yang rumit jadi tidak bisa dilakukan secara online.

Saya: menurut kamu, apakah pembelajaran matematika berbasis e-learning ini efektif atau tidak?

Responden: tidak efektif karena pembelajaran matematika sangat rumit jika diajarkan secara online dan saya paham jika diajarkan secara lamgsung oleh guru.

Berdasarkan wawancara yang telah dilakukan terlihat bahwa responden (R3) yang memiliki hambatan e-learning terhadap pembelajaran matematika tergolong sangat tinggi mampu menjawab pertanyaan yang diajukan oleh pewawancara dengan jelas dan sesuai dengan pertanyaan. Responden yang tergolong sangat tinggi menyatakan bahwa responden masih terkendala dengan penggunaan aplikasi pembelajaran dan responden tidak paham jika diajarkan oleh guru secara online karena hasil belajarnya menjadi menurun.

Dalam proses pembelajaran matematika berbasis e-learning tersebut terdapat kendala atau hambatan yang dialami oleh siswa. Hal ini terlihat dari analisis data penelitian menyimpulkan bahwa hambatan tersebut bisa berupa jaringan internet, hal ini paling sering dialami oleh siswa karena untuk mengakses materi pembelajaran matematika melalui koneksi internet. Jika jaringan intenet tidak stabil mampu berpengaruh terhadap motivasi belajar siswa menurun motivasi belajar siswa sehingga siswa sudah tidak ingin belajar dan tidak dapat mengerjakan dengan sungguh-sungguh (Albab, 2020).

Selain itu terdapat hambatan dalam pembelajaran matematika berbasis e-learning yaitu guru menggunakan model pengajaran yang kurang maksimal. Dalam proses pembelajaran peran guru sangat penting karena guru salah satu untuk menentukan kondisi pembelajaran yang terjadi di kelas maupun disekolah (Juniarti \& Gustiana, 2019). Sehingga dalam wawancara tersebut guru hanya belajar melalui google classroom sehingga materi yang diajarkan tidak dijelaskan kepada siswa sehingga siswa tidak paham dengan materi tersebut. Siswa menyatakan dalam wawancara bahwa matematika tidak bisa diajarkan secara online karena pembelajaran matematika berkaitan dengan rumus-rumus dan teori matematika sehingga siswa butuh bertahap dalam proses pembelajarannya.

Hambatan yang sering terjadi yaitu dalam penggunaan media pembelajaran. Dalam perkembangan teknologi mampu dimanfaatkan untuk mengembangkan pembelajaran yang baik yang digunakan untuk kegiatan pembelajaran supaya penyampaian materi dapat diterima oleh siswa, sehingga siswa mampu paham dan mengerti suatu materi yang diajarkan oleh guru (Febryana et al., 2020). Wawancara tersebut bahwa siswa mengalami kendala dalam penggunaan media pembelajaran dan siswa selama mengikuti proses pembelajaran matematika merasa bingung karena berbeda dengan pembelajaran matematika yang dilakukan secara tatap muka. Maka siswa mengalami penurunan terhadap hasil pembelajaran matematika. 


\section{KESIMPULAN}

Berdasarkan hasil paparan diatas yang berkaitan dengan hambatan e-learning terhadap pembelajaran matematika yaitu siswa dengan pembelajaran daring/online mengalami hambatan dalam proses pembelajaran matematika masih tergolong sangat tinggi. Hambatan yang dialami oleh siswa yaitu jaringan internet yang kurang stabil sehingga mampu berpengaruh terhadap motivasi belajar siswa, model pengajaran yang dilakukan oleh guru kurang maksimal sehingga mampu berpengaruh dengan pemahaman matematis siswa dan siswa mengalami kesulitan dalam penggunaan aplikasi pembelajaran.

\section{REFERENSI}

Aditya, P. T. (2018). Pengembangan Media Pembelajaran Matematika Berbasis Web Pada Materi Lingkaran Bagi Siswa Kelas Viii. Jurnal Matematika Statistika Dan Komputasi, 15(1), 64. https://doi.org/10.20956/jmsk.v15i1.4425

Agustina, M. (2013). Pemanfaatan E-learning sebagai Media Pembelajaran. Seminar Nasional Aplikasi Teknologi Informasi (SNATI), 12, 8-12.

Alariqi, A. A., Najafi, M., Abdulrab, M., Murray, C., \& Slimanzai, H. (2019). Factors affecting e-learning effectiveness in a higher learning institution in Afghanistan. ACM International Conference Proceeding Series, 176-181. https://doi.org/10.1145/3369255.3372275

Albab, S. U. (2020). Analisis kendala pembelajaran e-learning pada era disrupsi di SMK Terpadu AlIslahiyah Singosari Malang. Mudir: Jurnal Manajemen Pendidikan, 2. http://ejournal.insud.ac.id/index.php/MPI/article/view/105

Ardiyanti, D. (2017). Aplikasi Model Rasch pada Pengembangan Skala Efikasi Diri dalam Pengambilan Keputusan Karir Siswa [Application of the Rasch Model on the Development of Self-Efficiency Scale in Student Career Decision Making]. Jurnal Psikologi, 43(3), 248.

Arifin, F., \& Herman, T. (2018). Pengaruh Pembelajaran E-learning Model Web Centric Course Terhadap Pemahaman Konsep Dan Kemandirian Belajar Matematika Siswa. Jurnal Pendidikan Matematika, 12(2), 1-12. https://doi.org/10.22342/JPM.12.2.4152.1-12

Balkist, P. S. (2020). ANALISIS HAMBATAN BELAJAR SISWA SMA PADA MATERI TRIGONOMETRI DALAM KEMAMPUAN PENALARAN MATEMATIS ( The Analysis of Senior High Students ' Learning Obstacles on Trigonometry in Mathematical Reasoning Abilities ). 1(2), 42-50.

Febryana, E., Matematika, P., Sultan, U., Tirtayasa, A., \& Serang, K. (2020). Pengembangan Media Pembelajaran Berbasis E-learning Menggunakan Chamilo pada Pembelajaran Segitiga dan Segiempat. 8(2), 265-276.

Fitri Alyani, R. Z. (2020). Penerapan Rasch Model: Analisis Adversity Quotient Siswa dalam Matematika. Math Didactic: Jurnal Pendidikan Matematika, 6(2), 226-234.

Glinka, T. (2008). Metode Penelitian Sosial (Issue October 2019).

Hal, A., Muhammadiyah, S. M. P., \& Dahlan, U. A. (2017). Aksiologiya : Jurnal Pengabdian Kepada Masyarakat Pendampingan Pembuatan E-learning Dengan Moodle Yang Dipadukan Dengan 
Software Matematika Geogebra Untuk Guru. 1(2), 135-141.

Johar, R., \& Subianto, M. (2019). Hasil Belajar Geometri Siswa SMP dengan Menerapkan PembelajaranBerbasis E-learning. 7(1), 185-192. https://doi.org/10.24815/jp.v7i1.13750

Juniarti, Y., \& Gustiana, Ev. (2019). JPE ( Jurnal Pendidikan Edutama ) Vol . 6 No . 1 Januari 2019. JPE (Jurnal Pendidikan Edutama), 6(1), 59-64.

Mailizar, Almanthari, A., Maulina, S., \& Bruce, S. (2020). Secondary school mathematics teachers' views on e-learning implementation barriers during the COVID-19 pandemic: The case of Indonesia. Eurasia Journal of Mathematics, Science and Technology Education, 16(7). https://doi.org/10.29333/EJMSTE/8240

Muntazhimah, M., Putri, S., \& Khusna, H. (2020). Rasch Model untuk Memvalidasi Instrumen Resiliensi Matematis Mahasiswa Calon Guru Matematika. JKPM (Jurnal Kajian Pendidikan Matematika), 6(1), 65. https://doi.org/10.30998/jkpm.v6i1.8144

Noor, M. E., Hardyanto, W., \& Wibawanto, H. (2017). Penggunaan E-learning dalam Pembelajaran Berbasis Proyek di SMA Negeri 1 Jepara. Innovative Journal of Curriculum and Educational Technology, 6(1), 17-26. https://doi.org/10.15294/ijcet.v6i1.15572

Purba, S. E. D. (2018). Analisis model Rasch instrumen tes prestasi pada mata pelajaran dasar dan pengukuran listrik [Rasch model analysis of achievement test instruments on basic subjects and electrical measurements]. Wiyata Dharma: Jurnal Penelitian Dan Evaluasi Pendidikan, 6(2), 142.

Rully Amrizal. (2016). IMPLEMENTASI PEMBELAJARAN BERBASIS BLENDED PADA MATA PELAJARAN MATEMATIKA KELAS VIII MTS SKRIPSI https://lib.unnes.ac.id/24045/1/1102412020.pdf

Sawitri, E., Astiti, M. S., \& Fitriani, Y. (2019). Hambatan Dan Tantangan Pembelajaran. Seminar Nasional Pendidikan Program Pascasarjana Universitas PGRI Palembang, 202-213.

Sumintono, B., \& Widhiarso, W. (2015). APLIKASI PEMODELAN RASCH PADA ASSESSMENT PENDIDIKAN. Trim Komunikata.

Suyedi, S. S., \& Idrus, Y. (2019). Hambatan-Hambatan Belajar Yang Mempengaruhi Hasil Belajar Mahasiswa Dalam Pembelajaran Mata Kuliah Dasar Desain Jurusan Ikk Fpp Unp. Gorga : Jurnal Seni Rupa, 8(1), 120. https://doi.org/10.24114/gr.v8i1.12878

Utami, Y. P., Alan, D., \& Cahyono, D. (2020). Study At Home: Analisis Kesulitan Belajar. Jurnal Ilmiah Matematika Realistik (JI-MR), 1(1), 20-26.

Wahyuni, A. (2017). Analisis Hambatan Belajar Mahasiswa Pada Mata Kuliah Kalkulus Dasar. JNPM (Jurnal Nasional Pendidikan Matematika), 1(1), 10. https://doi.org/10.33603/jnpm.v1i1.253 